\title{
Representations of the French Language in the Detective Novel Sous les vents de Neptune by Fred Vargas
}

\section{Kathleen Shields}

National University of Ireland Maynooth

\begin{abstract}
This essay studies the role played by the two equally important varieties of the French language (Québécois and Parisian) present in Sous les vents de Neptune (2004) by Fred Vargas, and sets the novel in the context of recent debates about the French language. Many topics in these debates are not so new, such as the inseparable link between language and nation, the enduring notions of clarity, logic and rayonnement as well as the idea of the universality and humanism of French, as evidenced in writings on francophonie. The freedom of writing in a popular genre enables Vargas to comment obliquely on these questions of language, to challenge assumptions and to propose an alternative view of both language and universality.
\end{abstract}

\section{Keywords}

clarity, detective fiction, francophonie, French language, nationalism, universality

\section{Detective fiction as laboratory}

Fred Vargas's novel Sous les vents de Neptune clearly belongs to the category of the roman noirpost-war detective fiction with ambitions to be a cultural narrative for its times (Gorrara, 2003: 1-2). Yet it differs from the rest of her work in its dramatisation of the French language as something that both separates and unites the novel's protagonists. Here, because a large part of the fiction is set not on French soil but in Canada, the chief protagonist Commissaire Adamsberg is presented as a metropolitan Frenchman and his cultural identity is marked by the Parisian French that he speaks, in contrast to the French of his Canadian counterparts. The French language itself thus plays a key role in this psychological suspense fiction that uses one of the recognisable conventions of the genre, namely the story of the suspect as detective (Todorov, 1977: 51).

Adamsberg's investigation of a series of 'trident' murders, in which a three-pronged garden fork is used as the murder weapon, is interrupted as he and his team are sent to Canada to undergo training in the latest detection methods using DNA and genetic fingerprinting. Most of the central part of

\section{Corresponding author:}

Kathleen Shields, French Department, School of Modern Languages, Literatures and Cultures, National University of Ireland Maynooth (NUIM), Co. Kildare, Republic of Ireland.

Email: kathleen.m.shields@nuim.ie 
the fiction is set in Canada for this training period. Yet the trident murderer follows Adamsberg there and he is nearly framed for a murder that takes place in Ottawa. The Canadian episodes are mainly focalised through Adamsberg as he undergoes a nightmarish sense of dislocation and as his Canadian colleagues now turn their investigation on him.

At a structural level it can be said that the gap between the Canadian and Parisian reading of events is mirrored by the two very different kinds of French in which the story is told. In much detective fiction the gap between what really happened and how the reader and narrator come to know about it gradually becomes closed through the work of the investigator, who manages to identify the relevant evidence and interpret it correctly (Todorov, 1977: 44-5). However, in this case it is Adamsberg's mindset that blocks the way to closing the gap, as his normal intuitive way of working (described by one of his Canadian colleagues as 'pelleter des nuages') comes close to failure. This structure is repeated in geographical terms as the sure parameters of the investigator-killer duo that operated on French soil are gradually undermined after Adamsberg leaves France for Canada, parameters that are finally modified when he returns to France at the end of the book. Adamsberg is decentred into another variety of French as he undergoes his crisis. When he returns to France he is culturally chastened as well as wiser and capable of a deeper understanding of events.

The structural level is important. However, Sous les vents de Neptune also engages in several interesting ways with debates about the French language that are taking place in the wider world outside the novel, in particular with the symbolic value of French as repository of cultural distinctiveness and universal values. The point is often made that noir fiction, as opposed to the whodunit, is a laboratory where matters of social and political importance can be freely debated, explored and challenged (Vanoncini, 2002: 17-19; Horsley, 2001: 12-13). Vargas's work has been described as gothic, as belonging to a non-realist strand of European detective writing in which the author is free to explore political and social issues and she herself has endorsed this view of her work. ${ }^{1}$ In an interview with a Canadian journalist she points to the freedom of detective fiction because it allows her to write outside the literary and political establishment: "on peut tout essayer en dehors de "la" littérature française'. One can also explore political issues (and the French language is periodically one of these) in an indirect way. 'Je doute que la littérature soit le lieu de combat politique frontal. Je crois plutôt que c'est un lieu de combat politique subliminal.' Her detective novels, she says, must be loosely structured to leave space for the reader to speculate and imagine: 'Il faut des blancs. Si je raconte tout au lecteur, je lui tue l'imaginaire' (Jarry, 2002).

What I wish to explore in this article is the intersection between contemporary language debates and other ways of considering the French language, as suggested by the laboratory of Sous les vents de Neptune. The book obliquely comments on three important aspects of current debates about the French language and shows that these are ultimately not important. First, the book circumvents the centrality of the language to nation building in France and the avoids the impasse of the symbolic value of French that remains unchallenged by both left and right in France today. Second, it points up the blind spots in metropolitan French self-awareness by challenging the geographical hierarchies that commonly dominate discussion of metropolitan centre and francophone periphery in both language and literature. Finally, by raising the issue of humanism, and of values common to all peoples, the book makes another oblique reference to the paradoxical claim of French (language and nation) to be both particular and universal.

\section{The symbolic value of French}

French, along with the other standardised European languages, is strongly marked by a Herderian discourse in which the primordial unity of language, nation and state is taken as given (Gal, 1989: 
355-6; Grillo, 1989: 64-5). Assumptions about the indissoluble link between language and ethnicity (one language, one nation) also dominate thinking in language planning in France as elsewhere (Blommaert, 1996: 207-10). In addition to this discourse, writings about French often also carry the unexamined belief in the language as logical, clear and universal. Rather than being seen as a tool for communication, or a site of creativity open to innovation and historical change, the French language is perceived as an object of memory.

Pierre Nora describes the objects of memory in one of his many prefaces to Les Lieux de mémoire as, 'si évidents qu'ils soient, et parce qu'évidents, ils sont largement inconnus'. These objects are part of 'notre héritage collectif, qui tire sa justification la plus vraie de l'émotion qu'éveille encore en chacun d'entre nous un reste d'identification vécue à ces symboles à demi effacés' (Nora, 1997: 20, emphasis mine). The justification for studying these symbolically powerful objects lies in the emotion called forth in us by what remains of a lived identification with these symbols which are half erased. The promise of Les Lieux de mémoire is to go beyond the objects themselves in order to study the workings of collective memory itself. Memory is not simply 'ce dont on se souvient' but rather 'là où la mémoire travaille' (Nora, 1997: 17-18). However, it is interesting to note that the section of Les Lieux de mémoire relating to the genius of the French language, written by Marc Fumaroli, does not deliver on this promise. Fumaroli's essay is disappointing because like many similar writings it repeats without question truisms about the clarity, logic and universality of the language. The emotional identification with the perceived qualities of the language is so strong within the French state boundaries that there is a reluctance on the part of authors writing on the language to study these qualities in detail.

Nevertheless, two useful works on the notion of clarity do explore the links between French linguistic nationalism and perceptions about the language among its users. Henri Meschonnic demonstrates from an exhaustive study of treatises about the French language that clarity is a rather empty symbol, deriving its value through sheer repetition, generation after generation (Meschonnic, 1997). For Pierre Swiggers clarity is a collective myth cultivated by brilliant minds from Rivarol onwards in defence of a national quality (Swiggers, 1987: 14-15). The defenders of clarity come from the fields of literature and diplomacy, rarely from a background in grammar and philology. Yet he argues that they have had a strong influence on all thinking about the language:

Il suffit de penser à quelques idées - ici reçues, la rejetées - auxquelles la pratique linguistique n'a pas été imperméable: la langue comme truchement de la pensée; l'écriture comme la transposition (fidèle ou perfide) de l'oral; l'évolution 'organique' des langues; le fil (supposé ou clamé) rouge entre langue et race. (Swiggers, 1987: 5)

In histories of the language French is taken to be unique, and is seldom compared to other languages, even though in terms of questions such as standardisation it has many features in common with them (Lodge, 1997: 18). Maria Colombo-Timelli observes in her survey of histories of the language published between 1990 and 2000 that with only one exception they are all dominated by ideological claims about the prestige of French (2001: 135). Another commentator points out that it is important for linguists to draw a clear distinction between, on the one hand, the functions of a language as a necessary tool of communication, and, on the other hand, the uses of the language that derive from the values ascribed to it. In other words it is important to draw a distinction between communicative and ideological functions (Truchot, 2002: 22).

At this stage in the discussion it may be useful to borrow Jan Blommaert and Jef Vershueren's working definition of 'ideology' as: 
any constellation of fundamental or commonsensical, and often normative, ideas and attitudes related to some aspect of social 'reality'. Usually, ideologies have a degree of persistence over time: similar ideologies are recoverable, to quote Maurice Bloch, 'from one power-holder to another' ... The commonsense nature of the beliefs, ideas and attitudes (i.e. commonsensical for those who hold the beliefs and attitudes) is manifested in the fact that they are rarely questioned ... sometimes even across various discourse genres. (Blommaert and Vershueren, 1998: 25)

The symbolic value of the French language tends to distort and overshadow enquiry that attempts to answer the questions, 'What is French and what can it do?' These questions have been asked outside the state boundaries of France in relation, for example, to Canada and to sub-Saharan Africa (Heller, 2003: 228; Djite, 1997: 148-9, 153-60). One reason why ideology and communicative functions are not teased apart in discussions about the language is that, in France in particular, language is an intimate part of what Étienne Balibar has called the 'nation form': 'the myth of origins and national continuity ... is ... an effective ideological form, in which the imaginary singularity of national formations is constructed daily, by moving back from the present into the past' (Balibar, 1991: 87). The two pillars of the nation form are language and race, the former infinitely open, the latter the hereditary substance of ethnicity constantly having to be redefined (1991: 103). To separate out ideological and communicative functions of the language would be to call the nation form into question.

At first glance it might appear that there are significant differences between Republicans and nationalists about what the role of the language should be in France today. While Republicans champion the universalist values of francophonie, nationalists focus on the language as a repository of French identity. Thus one group can be accused of purism and prescriptivism while the other can be accused of neo-colonialism. Yet, as the linguist Robert Chaudenson observes, when it comes to the language there are few fundamental differences between right and left: "nationalism is a value shared by both the Communist Party and the French far right, a fact at once strange if explicable' (Chaudenson, 2003: 291). The core values of logic, clarity and universality remain intact and unexamined by nationalists and multiculturalists alike. A passive ethnocentrism lies at the heart of discussions about the language, whether the points being made are particularist or universalist. ${ }^{2}$

Sous les vents de Neptune is an unusual text in that it ignores the symbolic value that the French of France, in particular the French of the Île-de-France, might have. The central Canadian section of the novel consists mainly of dialogues in two varieties of French, the French spoken in Canada and the French of France, dialogues which send up the mutual incomprehensibility of Parisian and Québécois speakers. Each type of French is presented as equally valid, with its own worldview. As we shall see, Parisian French has no particular monopoly on logic, clarity or universality.

It is the non-universality of the French language that frames the central question raised by Sous les vents de Neptune, namely whether mediation or mutual comprehension are at all possible between different cultures. There are in the book at least three possible ways of engaging with the other, none of them unproblematic. These are through humour, through translation and through violence. I shall deal with the topic of violence in the final part of this article when I come to discuss Fred Vargas's humanism. Humour might appear to be a great leveller, a way around mutual incomprehension. Take, for instance, two apparently identical pieces of dialogue from the beginning of the Canadian section. The first speech contains Commissaire Adamsberg's instructions to the French team before they go on their 'mission Québec'. Here his patronising attitudes to Canadian French are on display, and through his cautioning against misrecognition of Canadian French an implicit sense of the rightness of his own way of speaking is revealed. 
C'est ce qu'il faut éviter: les rires. Leurs noms et leurs prénoms ne ressemblent pas aux nôtres. Vous trouverez à la GRC [Gendarmerie Royale du Canada] des Ladouceur, des Lafrance, et même des Louisseize. Pas de rires. Vous rencontrerez des Ginette ou des Philibert plus jeunes que vous. Pas de rires non plus, pas plus qu'à propos de leur accent, de leurs expressions ou de leur manière de parler. Quand un Québécois parle vite, ce n'est pas si facile à suivre. (Vargas, 2004: 109)

Several pages later we encounter the Canadian Surintendant Laliberté's advice to his team when they first meet the French. The language difference is mentioned but the main point is here that the French are apprentices in the Canadians' methods: they must be treated with understanding but not as if they are complete idiots.

- Chacun de vous s'amanchera avec l'un des membres de la Brigade de Paris, et on changera les paires tous les deux ou trois jours. Allez-y de tout cœur mais menez-les pas tambour battant pour vous faire péter les bretelles, ils ne sont pas infirmes des deux bras. Ils sont en période d'entraînement, ils s'initient. Alors formez-les au pas de grise pour commencer. Et faites pas de l'esprit de bottine s'ils ne vous comprennent pas ou s'ils parlent autrement que nous. Ils sont pas plus branleux que vous autres sous prétexte qu'ils sont français. Je compte sur vous.

En somme, à peu près le même discours que celui qu'Adamsberg avait tenu à son équipe, quelques jours plus tôt. (Vargas 2004: 132-3)

The narrator comments that these two speeches are really roughly the same. However, there are important differences on both sides, since the French team's cultural superiority might tempt them to laugh at the Canadians and the Canadians' scientific superiority might lead them to mock the French. The underlying point is that cultural superiority is similar wherever it is to be encountered and needs to be mocked, whether it is linguistic or technological.

Is there such a thing as the French language? Increasingly, the idea of 'le français standard' is being replaced by the concept of 'le français normé', where each variety of French approximates towards a français normé from its own regional base (Klinkenberg, 1999: 516; Chaudenson, 1993: 387). This is probably a fairly realistic description, as communities use their own vernacular French, they acquire the standard written forms through education, and individuals work out a balance between the two in different contexts. The written standards have not really been agreed upon but history and educational textbooks mean in practice that the French of the Île-de-France really still is the cultural and written norm (Martel, 1999: 85).

In contrast with the Canadian characters in Sous les vents de Neptune the French are bookish in their speech and incapable of metaphoric expression, as well as being monosyllabic, stiff and overformal. This is how one of the Canadian characters, a night watchman, puts it when he meets Commissaire Adamsberg for the first time:

- T'es du vieux pays? Français, hein?

- Oui.

- Comment je le sais? Dit l'homme en riant cette fois, et en s'approchant d'Adamsberg. Parce que quand tu parles, je crois pas t'entendre, je crois te lire. Tu fais-tu quoi par là? Tu vas aux hommes? (Vargas, 2004: 151)

Throughout the book Vargas undermines the idea that there is such a thing as the French language. There is in the book 'un français normé' specific to Canada and one specific to France but these are literary creations, as we shall see. The language is not an object of memory, 
a place of self-repossession or, as Nora would term it, 'une mémoire ressaisie' (Nora, 1997: 19). Instead it is presented as a site of confrontation between two, and sometimes even more than two, different cultures.

This is clear from the treatment of the question of translation. Translation does not seem to work too well as a way of mediation if we are to judge from the fate of the only interpreter figure in the book, the young Frenchwoman Noëlla. At the start of the central Canadian section she is perforce in the fiction to interpret from Canadian to Parisian French. Indeed, her function is to be a kind of walking translator's note in the text, as this typical example, when she and Adamsberg first meet, shows:

- Comment t'appelles-tu?

- Jean-Baptiste.

- Mais ton nom?

- Adamsberg.

- Et tu fais quoi?

- Flic.

- C'est marrant, ça. Les flics ici, c'est les bœufs, les chiens, ou les cochs, comme les cochons. Mon chum les aimait pas. 'Check les bœufs!' il disait. 'Vise les flics!', quoi. Et il se tirait aussi sec. Tu travailles avec les cops de Gatineau? (Vargas, 2004: 137-8)

Noëlla's own French is a little strange, not just because she has adopted Canadianisms like 'cops' and 'chum' into her vocabulary, something that also happens to Adamsberg's own speech and thoughts as the novel progresses. Her tendency always to refer to herself in the third person and by name is not only a matter of idiolect but also a sign of her mental fragility, as another passage of dialogue between herself and Adamsberg shows. She and Adamsberg hear from a barman that her boyfriend does not live on the right side of the law ('il piquait des chars') and that there is an article all about him in the local newspaper. Not that Adamsberg grasps more than the gist of the barman's account since he has to rely on Noëlla to explain the barman's words:

- Noir sur blanc dans le quotidien de Hull. Un soir, il s'est paqueté le beigne et les cochs l'ont pogné par les gosses. Il a pris sa débarque et je peux te dire qu'il n'est pas sorti du bois. C'était un maudit chien, ton chum. Alors assieds-toi dessus, puis tourne. J'avais le goût de te le dire, pour pas que tu le regrettes. Excuse-moi, j'ai une table qui m'appelle ...

- 'Assieds-toi dessus, puis tourne', répéta Adamsberg. Qu'est-ce qu'il te conseille? D'oublier? D'effacer?

- Non. Ça veut dire 'Arrête-toi un moment sur le truc et réfléchis bien.'

- Et 'se paqueter le beigne'?

- Se prendre une foutue cuite. Ça suffit, Noëlla n'est pas un dictionnaire.

- C'était pour comprendre ton histoire. (Vargas, 2004: 146)

In functional terms Noëlla is there to train the reader in the art of decoding the parallel dialogues in the two varieties of French. For this reason, as the reader becomes adept at translating, the figure of Noëlla becomes no longer necessary to the narrative.

In thematic terms, however, Noëlla undergoes a fate that is commonplace for many fictional translator and interpreter figures. Frequently, in book and film encounters between New World and Old World civilisations, interpreters are represented as ambivalent and untrustworthy figures, such as La Malinche, who interpreted for Cortés during the conquest of Mexico, or else they are depicted undergoing extraordinary distress and discomfort as they bear the brunt of cultural miscomprehension 
(Cronin, 2009: 34, 43, 92). Translation enables understanding and dialogue to take place, for both Adamsberg and the reader, but as far as Noëlla's destiny is concerned she pays the price with her own life. She is simply used by Adamsberg for a one-night stand and is later found murdered. In this way the plot implies that mutual comprehension between cultures can come about, yet at the cost of terrible violence perpetrated on the mediator.

Vargas is constantly at pains in the dialogues to stress difference, incomprehension and the otherness of the other on both sides. 'Être dur de comprenure' is a phrase that is repeated many times in the dialogues. And yet comprehension does take place in a messy, gapped sort of way, since bafflement and confusion force the protagonists to be aware of their own blind spots and to reformulate and make explicit the way they see things, as this typical exchange shows. Adamsberg's opposite number Sanscartier is about to change partners to work with a new member of the French team, a large woman called Violette Retancourt:

- Et toi? Avec qui travailles-tu?

- Avec celle qu'est tendre d'entretien. Tu peux-tu me rappeler son nom?

- Tendre d'entretien?

- Grosse, traduisit Sanscartier, embarrassé.

- Ah. Violette Retancourt. (Vargas, 2004: 167)

If a symbolic value can be ascribed to the French in the book, or rather to the two varieties of French, then it can be said that the language we use stands for all that is intuitive, not thought out and unexamined in the way we see ourselves in relation to others. In this way Sous les vents de Neptune dramatises what Pierre Swiggers has called the ambivalence at the very heart of language, itself both an object and an instrument of appropriation and alienation (Swiggers, 1987: 5).

\section{Centre and periphery}

In studies of the language from the time of Ferdinand Brunot onwards there has been a canonical division between the 'français de France' and the 'français hors de France'. This separation between French in France and French everywhere else is paralleled in literary studies by the distinction between 'littérature française' and 'littérature francophone'. It is a commonplace when referring to literature and language to use the expression 'la France et les pays francophones', as if France was somehow not a francophone country itself, as journalists have pointed out (Peroncel Hugoz, 1993: 17). In fact the expression ought to be 'la France et les autres pays francophones' (Anon., 1991: 6). There is a blindness to French, or at the least an unwillingness to examine it too closely, at the very heart of the centre.

The independence of the former colonies coincided with the emergence of francophonie as a loose political entity. Correspondingly, in the study of French language and literature there has been over the last 40 years a shift of attention away from the old centre towards the peripheries. This has resulted in a great number of studies of varieties of French and the literatures of the former colonies and the old periphery without an equivalent consideration of the old centre. The disciplinary pull towards the peripheries is evident, for instance, from the Louvain bibliography, La Francophonie internationale (Biblouvain, 2002). In addition, in disciplinary terms it is interesting to see how much research is conducted at the interface peripheries in regions and countries bordering France. There is a blind spot at the centre where republican ideals of universal francophonie engender a reluctance to consider the question of what French is, perhaps for fear of appearing too nationalistic. Constant focus on the other allows for attention to be diverted away from the self. 
Far from being a disturbing concept, alterity has become such a commonplace way of looking away from the self that one of its antonyms, identity, almost seems taboo. It is a short step from the eye that does not see itself to the eye that will not see itself, or that refuses to see itself. Things are sometimes consigned to the attic of memory because we do not wish to look at them. This is an aspect of cultural memory recently explored in German studies, for example by Budick and Iser and their colleagues, particularly in relation to alterity, when alterity means co-opting the memory of the other and avoiding self-examination (Motzkin, 1996: 265-81). A similar argument is that in France the concepts of alterity and diversity are often used to mask the lack of democracy in cultural policies and funding (Benhamou, 2004: 93).

The French language is an essential element of cultural identity in France which nevertheless tends to be avoided by the metropolitan or Île-de-France cultural and political elites. As a journalist in Le Monde put it in 1987, there is not much interest shown in 'la francophonie' by the 'maison mère' (Peroncel Hugoz, 1987). As far as the language goes this might be about to change, and it may well be that the French used in the territory of France is emerging as a new research area, in particular the urban French of the banlieues and of second-generation immigrants (Duchêne, 2002; Melliani, 2000). In the field of literature, despite Maryse Condé's argument that the expression 'litterature francophone' is now empty of meaning and only useful as a publishers' marketing device, the separation between centre and periphery is still very strong in France (Apter, 2001: 93). There is a conceptual fault line running through language, literature and politics that separates French inside and outside France, and that keeps a distance between core and periphery literatures as well as between core and periphery nations. Jumping, or slipping, from one field to another allows the fault line to be maintained, unexamined. This manoeuvre means that the French language can somehow be the basis for both particular and universal values and be the privileged vehicle for these values. We shall see an example of this in the concluding discussion of Vargas's brand of humanism in Sous les Vents de Neptune.

In the context of contemporary francophone writing the novel is unusual, since it shows a metropolitan writer dramatising an encounter between the old centre and the new world in terms of a stylised and at times caricatural clash between languages. This kind of dual awareness of old and new worlds together was, for example, present at the dawn of Caribbean writing in French, as Régis Antoine has shown (Antoine, 1978: 278-83). However, a metropolitan writer creating a work that situates France in relation to another non-French country was far from usual in 2004. The book stands out for two reasons: first because it includes the Parisian side of the equation and, second, because it presents an encounter which forces the Parisian protagonist to call into question his own assumptions about his personal and cultural identity. It is important to note that the Canadian French, although presented in a highly stylised and conventional way, is not in itself the subject of ridicule and mockery. As Vargas's Canadian interviewer puts it, there are many types of twinning or 'gémellité' to be found in her writing (Jarry, 2002). Parisian and Canadian French are paired and contrasted throughout, serving as foils for each other. The Canadian French is rich in metaphor, idioms and catchphrases all rooted in the physical and geographical realities of the continent, whereas the Parisian French is equally stylised, as a plain language from which these features are lost or banished. This is particularly so in the case of Adamsberg from whose speech all visual images are repressed, only to resurface in his dreams and nightmares.

When the book was published, readers and reviewers commented on the passages of Canadian French dialogue. Perhaps surprisingly, these parts of the book were most sharply criticised on the French side of the Atlantic. French-speaking Canada has many creative writers who use regional varieties of Canadian French and who are adept at negotiating pathways around and between these and the standard written language. Vargas cannot really compete with these authors and she does not try. She uses a narrow base of repeated Canadian vocabulary - all women are des blondes, cars 
are des chars, colleagues are des chums. Esti (for hostie) and maudit are fairly frequent adjectives. When it comes to syntax, she repeatedly uses two stylised elements: one is the interrogative form, as in 'tu-comprends-tu?', 'tu-peux-tu?, 'tu-cherches-tu quelque chose?' The other is the negative imperative, as in, 'inquiète-toi pas'. My own Canadian informant told me that there was nothing particularly wrong or strange about the Canadian French parts. For the non-speaker of Canadian French these passages of dialogue succeed in functional terms in that they create in the reader the feeling of a very different way of using language and of engaging with the world.

The reaction of some readers in France therefore seems excessive, some responding negatively to what one terms Vargas's 'pseudo-Québécois', others expressing shock at her lack of research and at the fact that she used no Canadian informants. ${ }^{3}$ As one French reader, Anne-Marie Kucharski (2004), says, this is:

le québécois tel qu'on ne le parle pas ... on rit beaucoup, et on se laisse prendre au québécois au point d'avoir l'accent constamment en tête en lisant les savoureux dialogues. Mais alors, pourquoi en refermant le livre ce sentiment d'un peu "too much"?

In contrast, the Canadian reviewers tended to read the book in the context of the rest of Vargas's work. It is clear that these French readers are missing the point, which is the juxtaposition of the two languages, not the colonialist parody of one of them.

\section{The universality of French}

The concept of rayonnement, of French radiating its clarity from the metropolitan centre throughout the francophone periphery, is an enduring part of French linguistic consciousness. The French of the metropolis in its standard written form is thus paradoxically universal and yet also specific to France. It is therefore possible to read the uneasy responses of French readers to Vargas's Canadian as an unwillingness to admit that French is not so universal after all. Certainly, the novel undermines the idea that one variety of French could or should be universal.

It was Léopold Sédar Senghor who most explicitly outlined the concept of rayonnement for the late twentieth century in his article in the journal Esprit published in 1962. Here the Senegalese writer is more French than the French themselves, echoing Rivarol's essay on the French language when he states that French is the 'Soleil qui brille hors de l'Hexagone' and that 'son rayonnement ne fait que s'étendre, même au Mali, même en Guinée' (Senghor, 1962: 844, 837). According to Senghor, French not only radiates its clarity and purity from the centre, but it is also better than African languages, for its abstract vocabulary and subordinating syntax. Explaining why French is attractive to African elites, he praises what he sees as the inherently superior qualities of the language, particularly its humanism and its universality. 'A la syntaxe de juxtaposition des langues négro-africaines, s'oppose la syntaxe de subordination du français; à la syntaxe du concret vécu, celle de l'abstrait pensé: pour tout dire, la syntaxe de la raison à celle de l'émotion' (Senghor 1962: 840). In 1962, at the dawn of independence for many African states, Senghor had his own political motives for making these points while he was positioning himself as one of the major founders of francophonie as a loose commonwealth of nations. What is interesting is how this essay has been used since then. It has recently been taken up by French commentators and used as a founding text for their promotion of a second era of francophonie as a movement of language and culture. ${ }^{4}$

Senghor's 1962 essay is a key text for the journalist Claire Tréan in her book that aims to dismantle some of the received ideas about francophonie. French is not only 'un humanisme' but also 'une langue à vocation universelle' (Tréan, 2006: [5], 20-1). She argues that while Senghor 
laid the foundations of francophonie in his essay the movement has progressed to a new stage since the fall of the Berlin Wall and 11 September 2001:

Elle [la francophonie] est passée, au fil des ans, d'une politique essentiellement axée sur le soutien à la langue française, et largement perçue comme purement défensive, à un combat beaucoup plus ouvert, auquel s'est ralliée l'écrasant majorité des pays du monde. (2006: 14)

She ridicules the defenders of the French language in France, dismissing them as 'un club de vieux messieurs portant nœud papillon, occupant leur retraite à traquer le maniement erroné de l'imparfait du subjonctif et, surtout, à guerroyer contre l'anglais' (2006: 23). However, the difference between 'ces papys combattants' and recent defenders of francophonie is more one of degree than of kind, more a difference of style and scale rather than a difference of ideas about French itself.

There is not much that is new in the arguments that Claire Tréan uses in defence of the language, and little that marks out the second era of francophonie as being different from the first, beyond the increasing global dominance of English and a weakening of the prestige of French. As an antidote to global uniformity and the clash of cultures, francophonie offers universality and humanity and while it is not simply a matter of language, the language is important. In this way a conceptual slippage between language, culture and prestige allows her to reintroduce the language back into the mix. For Tréan, French needs to keep its status as an international language of communication (2006: 32). 'La promotion du français reste, pour les pays qui se réclament de l'ensemble francophone, une priorité, une sorte de justification existentielle, une des conditions pour en être' (2006: 37). The trinity of French language, universality and humanism remains intact.

The well-known linguist Claude Hagège also cites Senghor's 1962 essay as an important milestone in his book Le Français, histoire d'un combat, which was an expanded version of a television series that he presented in 1996. Hagège has a clear sense of what was at stake politically in the 1960s and an awareness of what differentiates that decade from the 1990s (Hagège, 1996: 138-9, 144). But in his concluding chapter on the future of French, he reiterates the points of Senghor's 1962 essay by reusing concepts such as rayonnement, humanism and universality. He argues that French has a special mission to speak on behalf of all languages that are not English, concluding, 'le combat en faveur de la langue française est aussi, à plus d'un titre, un combat pour l'humanité' (1996: 167-8). Defenders of the nation form, whether in its inclusive or exclusive varieties, do not wish to let go of the universality of French.

In Sous les vents de Neptune, Vargas detaches issues of humanism and universality from the French language. Instead the question of humanism is linked to debates about relativism (people are fundamentally the same except that they are different), particularly where the encounter between different civilisations leads to violence and death. While the encounter is expressed through the medium of different kinds of French, it gradually becomes clear that Vargas's brand of humanism does not depend on the French language as its basis.

This is especially evident in the parts of the novel where the older peoples that pre-date Champlain make an appearance. Here the encounter between two cultures is not between French speaker and French speaker but between French settlers and Native Canadians. Noëlla's death is shadowed by the violence of an earlier encounter between Native Canadians and French, centuries before. The native people of Ottawa, the Outaouais and the Iroquois, are presented as the most extreme form of the incomprehensible other. Part of Adamsberg's trouble with Noëlla, as he sees it, arises from her conviction that she is to bear his child because this fate was foretold to her by 'le vieil Indien Shawi', an old Algonquin seer, who is descended from the Outaouais (Vargas, 2004: 177). Adamsberg, as a figure from the Old World, is suspicious of his compatriot Noëlla on the grounds that she has perhaps 
gone native. Up to this point the reader has been interpreting the Canadian French alongside Adamsberg and seeing Canada through his eyes. However, Noëlla's death and Adamsberg's deeply unsympathetic treatment of her mark a turning-point in the narrative where the reader begins to disengage from the focalisation through him.

One of the leitmotifs in Adamsberg's mental furniture is a lake north of Gatineau, 'le lac Pink' and the strange prehistoric fish that lives in its waters. The lake is described as 'un lac vivant posé sur un lac mort', a living lake on top of a dead one. The two types of waters in the lake can be read as a metaphor for non-translatability, incomprehension and lack of connection between obsessive dreams and rational science. In terms of the quest structure of the thriller they reveal the lack of connection in Adamsberg's mind between the nightmarish living present of serial killings and the historical evidence needed to make sense of it. Need every encounter with the other come to a violent end? Are other means of cultural mediation possible? The stage is set for Vargas's humanism which emerges in the final part of the book.

Adamsberg's Parisian ways, symbolised by his humourless, literalist standard French; his conviction that his intuitive policing method is the right way of doing things; and his suspicion of the Canadians, are all so many blinkers preventing him from selecting the right evidence to interpret. Because of shifts in the focalisation, so that the narrative is intermittently seen through his eyes, these irrational phobias are presented as part of his own mental baggage bordering on obsessive paranoid delusions. Towards the end of the Canadian section the older encounter between Native Canadian and French resurfaces. When Adamsberg becomes convinced that the Canadians have been conspiring against him all along, the darker theme of cannibalism is introduced. Pending the enquiry into him Adamsberg is accommodated at the Hôtel Brébeuf. He asks a Canadian colleague about the name Brébeuf:

- C'est le nom d'un gars, Brébeuf?

- Oui, d'un Français buté comme une mule qui s'est fait bouffer par les Iroquois parce qu'il voulait leur prêcher des menteries. (Vargas, 2004: 225)

We have here shades of Montaigne's cannibals. It is interesting that the Canadian's perspective on the encounter is a sceptical one: for him the Frenchman Brébeuf was stubborn and his religion was a pack of lies ('il voulait leur prêcher des menteries'). The reader is nudged towards a relativist position, since the Canadian's viewpoint is a valid one, and the suggestion is that Brébeuf and Adamsberg are not dissimilar. The problem, as the book lays it out, is how to find a way of connecting the two different perspectives.

The two cultures that need to be connected into one whole are in fact not the French of Canada and the French of Paris. Rather, in order to make sense of the overwhelming mass of archival and DNA material, in order to know what to select so that interpretation of evidence can take place, the two cultures that need to be joined are the scientific and the intuitive. In the contrast between the practices of cultural memory on the one hand (dreams, obsessions, institutions and language) and hard evidence on the other (photography, DNA, computer databases, state archives), it becomes clear that decoding within the former drives the latter to solutions - and vice versa. The two cannot be separated if the mystery is to be solved. Vargas's humanism is one that argues for interconnections between scientific and other forms of knowledge (for example, linguistic and historical) since only in this way can human beings understand one another and progress.

The conclusion of Sous les vents de Neptune reflects Vargas's own career in that she straddles the sciences and the humanities - by profession a research archaeologist specialising in animal bones as a key to understanding village settlements in the Middle Ages. With the outstanding success 
of her fiction she could have given up archaeology to live by her pen, but chose not to do so, but she has stated that she needs the freedom that the day job gives her so that she can continue to experiment in a popular genre. In this way she can remain detached but not disengaged from debates about language.

In Sous les vents de Neptune ideas about language are explored from both humorous and didactic motives. Language, in this instance French, is not important for its symbolic value or as an object of memory, but rather as a tool for communication. As such it can too easily become both an instrument and an object for separating ourselves from those we perceive to be the others, whether they are French or Canadian. The French language in itself is not a vehicle for universals of humanity or the workings of the human mind.

As a laboratory, Sous les vents de Neptune bears interesting comparison with another detective novel, Sérail killers by Lakhdar Belaïd, in which comical multilingual dialogue takes place between French, chtimi and Arabic (Belaid, 2000). The coexistence within the territory of France of dialect, national language and the major other language (Arabic rather than English) is a subject rarely touched upon in the language debates. In Sous les vents de Neptune, Vargas bypasses the symbolic value of metropolitan French by putting Canadian and Parisian French on an equal footing, thus avoiding the impasse of the debate between left and right over whether the role of the language is to be inclusive or a sign of identity. The book subverts the common relations between centre and periphery that allow for the predominance of metropolitan French. At the same time it discounts any monopoly that the French language might claim to have on humanism. This is refreshing in a context where much commentary on the language oscillates between triumphant statements about its prestige and despair at the domination of global English, between 'francophone bluster and an acceptance that English now rules' (Supiot, 2006: 25).

\section{Notes}

1 In a BBC Radio 4 documentary Open Book on European crime fiction (Bartlett and Von Hurter, 2006).

2 In a different context Michel Winock makes a similar point about anti-Semitism in France. There is, he says, not much difference between two ethnocentrisms that fed into anti-Semitism: 'Deux ethnocentrismes inverses ("culturocentrismes" serait peut-être mieux dire) ont concouru à créer ou à envenimer l'antisémitisme: un ethno-culturocentrisme singulariste ou différentialiste et un ethno-culturocentrisme universaliste' (Winock, 2004: 186).

3 Irène De Los Santos (2004) uses the expression 'pseudo-québécois'. The reception of the book is described by Anne-Marie Kucharski (2004). For a short biography of Fred Vargas, see Liard (2005).

4 Michel Tétu distinguishes between three meanings, and different spellings, of the word francophonie: (i) francophonie (lower case $\mathrm{f}$ ) as the fact of speaking the French language and using it during the course of one's everyday business; (ii) Francophonie (upper case F) as a political term meaning the loose affiliation or commonwealth of nations, most of which use French; (iii) francophonie (lower case f) as a cultural and literary phenomenon (Tétu, 1997: 14).

\section{References}

Anon. (1991) La Mal-aimée des Français. Le Monde, 20 November, 6.

Antoine R (1978) Les Écrivains français et les Antilles. Paris: Maisonneuve et Larose.

Apter E (2001) Crossover texts/creole tongues: a conversation with Maryse Condé. Public Culture 13(1): 89-96. Balibar É (1991) The nation form. In: É Balibar and I Wallerstein (eds) Race, Nation, Class, trans. Chris Turner. London: Verso, 86-106.

Bartlett D, Von Hurter F (2006) Open Book (BBC Radio 4 documentary on European crime fiction). Available at: www.bbc.co.uk/radio4/arts/openbook. 
Belaïd L (2000) Serail Killers. Paris: Gallimard.

Benhamou F (2004) L'Exception culturelle: exploration d'une impasse. Esprit May: 85-113.

Biblouvain (2002) http://cifdi.francophonie.org/Biblio/Biblouvain/index.html.

Blommaert J (1996) Language planning as a discourse on language and society. Language Problems and Language Planning 20: 199-222.

Blommaert J, Vershueren J (1998) Debating Diversity: Analysing the Discourse of Tolerance. London: Routledge.

Chaudenson R (1993) Francophonie, 'français zéro' et 'français régional'. In: D de Robillard and M Beniamino (eds) Le Français dans l'espace francophone. Paris: Champion, 385-405.

Chaudenson R (2003) Geolinguistics, geopolitics, geostrategy: the case of French. In: J Maurais and MA Morris (eds) Languages in a Globalizing World. Cambridge: Cambridge University Press, 291-7.

Colombo-Timelli M (2001) Francophonie et histoire(s) de la langue française: un bilan des dix dernières années (1990-2000). Ponts 1: 135-57.

Cronin M (2009) Translation Goes to the Movies. London: Routledge.

De Los Santos I (2004) Sous les vents de Neptune. Available at: www.mauvaisgenres.com/fred_vargas.htm.

Djite P (1997) Francophonie et pluralisme culturel. Australian Journal of French Studies 34(2): 145-65.

Duchêne N (2002) Langue, immigration, culture: paroles de la banlieue française. Meta 47(1): 30-7.

Gal S (1989) Language and political economy. Annual Review of Anthropology 18: 345-67.

Gorrara C (2003) The Roman Noir in Post-War French Culture: Dark Fictions. Oxford: Oxford University Press.

Grillo RD (1989) Dominant Languages: Language and Hierarchy in Britain and France. Cambridge: Cambridge University Press.

Hagège C (1996) Le Français, histoire d'un combat. Paris: Livre de Poche.

Heller M (2003) Alternative ideologies of la francophonie. In: R Harris and B Rampton (eds) The Language, Ethnicity and Race Reader. London: Routledge, 225-42.

Horsley L (2001) The Noir Thriller. Basingstoke: Palgrave.

Jarry J (2002) Entrevue avec Fred Vargas - silence, on meurt. Le Devoir (Montreal) 23 and 24 November. Available at www.ledevoir.com.

Klinkenberg J-M (1999) La Francophonie septentrionale. In: J Chaurand (ed.) Nouvelle histoire de la langue française. Paris: Seuil, 510-43.

Kucharski A-M (2004) Fred Vargas: Sous les vents de Neptune. Available at: http://artslivres.com, no. 5.

Liard J (2005) Qui est Fred Vargas? Available at: www.linternaute.com/sortir/auteurs/fred_vargas/vargas.shtml.

Lodge RA (1997) Le Français: histoire d'un dialecte devenu langue. Paris: Fayard.

Martel A (1999) Culturally colored didactics: the sociopolitical at the heart of second/foreign language teaching in francophone geolinguistic spaces. Instructional Science 27(1-2): 73-96.

Melliani F (2000) La Langue du quartier: appropriation de l'espace et identités urbaines chez des jeunes issus de l'immigration maghrébine en banlieue rouennaise. Paris: L'Harmattan.

Meschonnic H (1997) De la langue française: essai sur une clarté obscure. Paris: Hachette.

Motzkin G (1996) Memory and cultural translation. In: S Budick and W Iser (eds) The Translatability of Cultures. Stanford, CA: Stanford University Press, 265-81.

Nora P (1997) Les Lieux de mémoire, 2nd edn. Paris: Gallimard.

Peroncel Hugoz J-P (1987) La Prise de conscience des Français. Le Monde, 2 January.

Peroncel Hugoz J-P (1993) Parler français: le désamour. Le Monde, 5 October, 17.

Senghor LS (1962) Le Français, langue de culture. Esprit, November: 837-44.

Supiot A (2006) The condition of France. London Review of Books, 8 June, 24-6.

Swiggers P (1987) A l'ombre de la clarté française. Langue Française 75: 5-21.

Tétu M (1997) Qu'est-ce que la francophonie? Paris: Hachette.

Todorov T (1977) The typology of detective fiction. In: The Poetics of Prose, trans. R Howard. Oxford: Blackwell, 42-52. 
Tréan C (2006) La Francophonie. Paris: Le Cavalier Bleu.

Truchot C (2002) L'Anglais en Europe: repères. Strasbourg: Council of Europe.

Vanoncini A (2002) Le Roman policier. Paris: Presses Universitaires de France.

Vargas Fred (2004) Sous les vents de Neptune. Paris: Viviane Hamy.

Winock M (2004) Nationalisme, antisémitisme et fascisme en France. Paris: Seuil.

Kathleen Shields is a lecturer in French at the National University of Ireland Maynooth. She was a senior editor on the Oxford-Hachette French Dictionary project and she is author of Gained in Translation: Language, Poetry and Identity in Twentieth-Century Ireland. Her research interests include dictionaries, translation studies and francophone language policy. She has published articles in these fields, most recently on metropolitan attitudes to French language and identity and on Senghor's translations. 